\title{
Interactions between ammonium and urea uptake by five strains of Alexandrium catenella (Dinophyceae) in culture
}

\author{
Cécile Jauzein $^{1,2}$, Sofia Loureiro ${ }^{3}$, Esther Garcés ${ }^{3}$, Yves Collos ${ }^{1, *}$ \\ ${ }^{1}$ Université Montpellier II, CC093, Laboratoire Ecosystèmes Lagunaires (UMR CNRS 5119), 34095 Montpellier Cedex 5, \\ France \\ ${ }^{2}$ Laboratoire Environnement Ressources/LR, Ifremer, BP 171, 34203 Sète, France \\ ${ }^{3}$ Dept Biologia Marina, Institut de Ciències del MAR, CMIMA-CSIC, Pg. Marítim de la Barceloneta 37-49, 08003 Barcelona, \\ Catalonia, Spain
}

\begin{abstract}
Short-term experiments were carried out to investigate whether interactions between ammonium $\left(\mathrm{NH}_{4}^{+}\right)$and urea uptake regulate the total nitrogen assimilation of the toxic dinoflagellate Alexandrium catenella. To test for strain variability, 5 strains of $A$. catenella from the NW Mediterranean were used: 3 strains from the Thau lagoon (southern France) and 2 strains from the Catalonia basin (Spain). For each strain, the uptake rate of 1 nutrient $\left(\mathrm{NH}_{4}{ }^{+}\right.$or urea) at a reference concentration $\left(10 \mathrm{gatN}^{-1}\right)$ was measured as a function of the increasing concentration of the other nutrient $\left(0\right.$ to $10 \mu$ gatN $~^{-1}$ ). Simultaneous $\mathrm{N}$ uptake rates of the distinct nitrogen sources were obtained from ${ }^{15} \mathrm{~N}-\mathrm{NH}_{4}{ }^{+}$and ${ }^{15} \mathrm{~N}$-urea incorporation measurements. A strong inhibition of urea uptake by $\mathrm{NH}_{4}{ }^{+}$ (maximum inhibition, $I_{\max }>55 \%$ ) was observed exclusively for the French strains. No influence of urea on the $\mathrm{NH}_{4}{ }^{+}$-uptake rate was noted for any strain. Estimation of total $\mathrm{N}$ uptake rates revealed that the N-urea uptake inhibition was not a competitive disadvantage for $A$. catenella cells considering that the reduced $\mathrm{N}$-urea uptake was more than compensated for by $\mathrm{NH}_{4}{ }^{+}$uptake. Furthermore, the computation of composite kinetic parameters from total $\mathrm{N}$ uptake data suggested that French strains were more competitive than the Spanish ones in an environment characterized by low $\mathrm{NH}_{4}{ }^{+}$

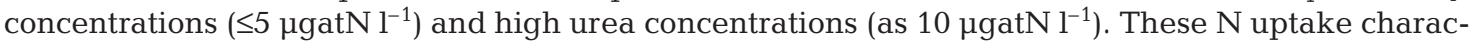
teristics may reflect particular metabolic adaptations by the strains to their respective environment.
\end{abstract}

KEY WORDS: Alexandrium catenella $\cdot$ Ammonium $\cdot$ Urea $\cdot$ Interactions $\cdot$ Strain variability

\section{INTRODUCTION}

During the last few years, recurrent toxic blooms of Alexandrium catenella have been observed in coastal waters of the NW Mediterranean Sea. In particular, this dinoflagellate species was detected for the first time on the Catalan coast of Spain in 1996 (Vila et al. 2001) and in the Thau lagoon, an intensive shellfish farming zone in France, in 1998 (Lilly et al. 2002). Physiological rate measurements on natural populations of A. catenella have shown that most of the dissolved nitrogen supply for growth comes from ammonium $\left(\mathrm{NH}_{4}{ }^{+}\right)$and urea (Collos et al. 2007). A large variability in uptake kinetic parameters was noted for both $\mathrm{N}$ sources, part of which could be attributed to differences in growth rate (Collos et al. 2007). Nevertheless, the interactions between $\mathrm{NH}_{4}{ }^{+}$and urea uptake were not taken into account in these investigations. Historically, urea has been relatively ignored as an $\mathrm{N}$ source compared to other compounds such as nitrate $\left(\mathrm{NO}_{3}{ }^{-}\right)$or $\mathrm{NH}_{4}{ }^{+}$, but recently, urea has been suggested to be a major factor leading to harmful algal blooms (Glibert et al. 2006).

Studies on interactions between $\mathrm{NH}_{4}{ }^{+}$and urea uptake by microalgae have been relatively few. In marine phytoplankton, Waser et al. (1998) found a variety of 
interactions. For example, N-sufficient cells of Chaetoceros debilis preferred $\mathrm{NH}_{4}{ }^{+}$to urea, while $\mathrm{N}$-starved cells took up urea first, and only upon exhaustion of this compound was $\mathrm{NH}_{4}{ }^{+}$taken up. For Emiliana huxleyi, $\mathrm{N}$-sufficient cells preferred $\mathrm{NH}_{4}{ }^{+}$and $\mathrm{NO}_{3}{ }^{-}$to urea, while starved cells took up $\mathrm{NH}_{4}{ }^{+}$first until exhaustion, and then urea, in preference to $\mathrm{NO}_{3}{ }^{-}$. For Thalassiosira weissflogii, $\mathrm{NH}_{4}{ }^{+}$had no effect on $\mathrm{N}$-urea uptake (Lomas 2004). In natural populations of phytoplankton in the Baltic Sea, Irmisch (1991) found that $\mathrm{NH}_{4}{ }^{+}$additions reduced urea uptake in a significant way. Such studies are complicated by physiological processes such as $\mathrm{NH}_{4}{ }^{+}$excretion that occurs during urea assimilation (Uchida 1976, Rees \& Bekheet 1982, Price \& Harrison 1988) and could lead to feedback regulation.

Bioassays have indicated $\mathrm{N}$ to be the limiting nutrient in the Thau lagoon for phytoplankton in general (Bec et al. 2005) and for Alexandrium catenella in particular (Collos et al. 2007). We present results of experiments designed to characterize the interactions between $\mathrm{NH}_{4}{ }^{+}$and urea uptake as well as to assess whether inhibition of one $\mathrm{N}$ source by the other leads to an increase in the overall uptake of this limiting resource. As significant differences in the $\mathrm{N}$ uptake and assimilation of $\mathrm{NH}_{4}{ }^{+}$have been noted previously between strains of A. catenella (Collos et al. 2006), several strains were used in order to examine this variability regarding the $\mathrm{NH}_{4}{ }^{+}$-urea interaction process.

\section{MATERIALS AND METHODS}

Culture conditions. The 5 strains used in this study were isolated from different Mediterranean coastal areas: VGO715 (Barcelona, Spain), VGO565 (Tarragona, Spain), and ACT03, TL01, and VGO815 (Thau lagoon, France). Strains were acclimated in cultures between 2002 and 2004, except for TL01 (isolated in 1998). Stock cultures were non-axenic and were maintained on enriched seawater with $\mathrm{NO}_{3}{ }^{-}$as an $\mathrm{N}$ source. Before and during the experiments, the cultures were grown at $20^{\circ} \mathrm{C}$ and exposed to $100 \mu \mathrm{mol}$ photons $\mathrm{m}^{-2}$ $\mathrm{s}^{-1}$ with a 12:12 h light:dark cycle using fluorescent tubes (Grolux, Sylvania). The culture media used were ESAW artificial seawater medium (Andersen et al. 2005) for ACT03 and TL01 strains and f/2 medium (Guillard \& Ryther 1962) prepared in $0.2 \mu \mathrm{m}$ filtered seawater for the other strains.

Interaction experiments. For each strain, the experiment started with the resuspension of Alexandrium catenella cells from the stock culture into 2.61 of medium with no $\mathrm{N}$ source. This resuspension step was performed by collecting the cells on a $10 \mu \mathrm{m}$ mesh net by gravity filtration and allowed for the withdrawal of most of the bacteria from the culture medium (Rausch de Traubenberg \& Soyer-Gobillard 1990). The cells were kept under these low $\mathrm{N}$ conditions for $6 \mathrm{~h}$ to ensure undetectable $\mathrm{NH}_{4}{ }^{+}$concentration in the medium at the beginning of the incubations.

Two series of incubations were then done successively to test the influence of urea on the maximal uptake rate of $\mathrm{NH}_{4}{ }^{+}\left(V_{\max }-\mathrm{NH}_{4}{ }^{+}\right)$and the influence of $\mathrm{NH}_{4}{ }^{+}$on the maximal uptake rate of $\mathrm{N}$-urea $\left(V_{\text {max }}{ }^{-}\right.$ urea). During each part of the experiment, the uptake rate of one nutrient at a reference concentration of $10 \mu$ gatN $^{-1}$ was measured as a function of the increasing concentration of the other nutrient $(0,0.1,0.2,0.5$, $1,2,3,5$, and $10 \mu$ gat $\mathrm{N}^{-1}$ ). The reference concentration $\left(10 \mu\right.$ gatN $\left.^{-1}\right)$ corresponds to the upper range of $\mathrm{NH}_{4}{ }^{+}$or urea concentrations observed in the field during Alexandrium catenella blooms in Spain and France (Garcés et al. 2005, Collos et al. 2007). For each part of the experiment, 2 incubations of $1 \mathrm{~h}$ were performed in parallel, based on the same nutrient regimes, but one in which the constant nutrient was labeled with ${ }^{15} \mathrm{~N}$ and the second in which the varying nutrient was labeled. The coupled incubations allowed measurements of simultaneous uptake of $\mathrm{NH}_{4}{ }^{+}$and $\mathrm{N}$-urea for all nutritive conditions. Incubations started with the addition of ${ }^{15} \mathrm{NH}_{4}{ }^{+}$or ${ }^{15} \mathrm{~N}$-urea into $50 \mathrm{ml}$ samples. At the end of the incubation period, all samples were filtered through precombusted $\left(4 \mathrm{~h}\right.$ at $\left.450^{\circ} \mathrm{C}\right) \mathrm{A} / \mathrm{E}$ filters (Gelman Sciences). Filters were dried at $60^{\circ} \mathrm{C}$ overnight and analyzed on an Integra $\mathrm{CN}$ elemental analysis-mass spectrometry system (PDZ Europa) to obtain measurements of particulate nitrogen (PN), particulate carbon $(\mathrm{PC})$, and ${ }^{15} \mathrm{~N}:{ }^{14} \mathrm{~N}$ isotopic ratio.

Nutrient analysis. Concentrations of different $\mathrm{N}$ sources $\left(\mathrm{NO}_{3}{ }^{-}, \mathrm{NH}_{4}{ }^{+}\right.$, and urea) were determined in the culture medium just after resuspension and at the beginning of each experiment part. Ammonium and $\mathrm{NO}_{3}{ }^{-}$concentrations were measured using a Technicon AutoAnalyzer ${ }^{\circledR}$ as described by Grasshoff et al. (1983) for VGO715, VGO565, and VGO815 and using, respectively, the methods of Koroleff (1976) and Collos et al. (1999) for TL01 and ACT03. Urea measurements were performed according to Goeyens et al. (1998).

Complementary measurements of $\mathrm{NH}_{4}{ }^{+}$concentration were done every 15 min during each incubation period to check for a potential excretion of $\mathrm{NH}_{4}{ }^{+}$linked with urea assimilation.

$\mathbf{N}$ uptake measurements. Measurements of ${ }^{15} \mathrm{~N}$ enrichments were converted to net uptake rates of $\mathrm{NH}_{4}{ }^{+}$ and N-urea according to Collos (1987). For urea uptake, inclusion of an ambient urea concentration higher than $0.5 \mu$ gat $~^{-1}$ in the calculation of ${ }^{15} \mathrm{~N}$-urea uptake rates led to apparent reverse kinetics (decrease in uptake rate with increasing urea concentrations) despite the fact that the ${ }^{15} \mathrm{~N}$ isotopic ratio increased 
along the urea gradient. Such patterns are thought to be due to overestimation of the ambient substrate concentration (Eppley et al. 1977, Sahlsten 1987, Kristiansen \& Lund 1989). Therefore, we chose to not include ambient urea concentration in ${ }^{15} \mathrm{~N}$-urea uptake calculations. Furthermore, a lack of change of $\mathrm{NH}_{4}{ }^{+}$ concentration in the medium during each incubation allowed the consideration that no $\mathrm{N}$ excretion losses have to be taken into account in $\mathrm{N}$-urea uptake estimations. Thus, net ${ }^{15} \mathrm{~N}$-urea uptake rates measured were equivalent to gross $\mathrm{N}$-urea uptake rates.

From simultaneous incubations, total $\mathrm{N}$ uptake rates (from $\mathrm{NH}_{4}{ }^{+}$and urea fluxes) were computed for each nutrient condition and strain, using:

$$
\rho_{\mathrm{N} \text {-tot }}=\rho_{\mathrm{N}}(\text { urea })+\rho_{\mathrm{N}}\left(\mathrm{NH}_{4}^{+}\right)
$$

where $\rho_{\mathrm{N} \text {-tot }}$ is the total influx of ${ }^{15} \mathrm{~N}$ (in $\mu$ gat $\mathrm{N}^{-1} \mathrm{~h}^{-1}$ ) for each nutrient condition and $\rho_{\mathrm{N}}$ (urea) and $\rho_{\mathrm{N}}\left(\mathrm{NH}_{4}{ }^{+}\right)$ are, respectively, the influx of ${ }^{15} \mathrm{~N}$-urea and ${ }^{15} \mathrm{NH}_{4}{ }^{+}$(in ugatN $\mathrm{l}^{-1} \mathrm{~h}^{-1}$ ) obtained from simultaneous incubations.

To compare strains, total $\mathrm{N}$ uptake rates $\left(V_{\mathrm{N} \text {-tot }}\right)$ from $\mathrm{NH}_{4}{ }^{+}$and urea (in $\mathrm{h}^{-1}$ ) were normalized to PN according to:

$$
V_{\mathrm{N} \text {-tot }}=\rho_{\mathrm{N} \text {-tot }} / \mathrm{PN}_{\text {mean }}
$$

where $\mathrm{PN}_{\text {mean }}$ (in $\mu$ gatN $\mathrm{l}^{-1}$ ) is the mean of $\mathrm{PN}$ values from both coupled incubations.

Modeled curves and kinetic parameters. When the relation between uptake rates and concentrations exhibited saturation kinetics, the Michaelis-Menten model was used to generate kinetic parameters from the original or modified equations depending on cases.

(1) For a specific nutrient, if saturable kinetics were observed in the relation between uptake rates and concentrations, uptake data were modeled using the Michaelis-Menten relation (Andersen \& Heibig 1998):

$$
V_{\mathrm{N}}=V_{\max -\mathrm{N}} \times[\mathrm{N}] /\left(K_{\mathrm{s}}+[\mathrm{N}]\right)
$$

where $V_{\mathrm{N}}\left(\mathrm{in} \mathrm{h}^{-1}\right)$ is the $\mathrm{N}$ uptake rate under a nutrient concentration of [N] (in $\mu$ gatN $\left.1^{-1}\right), V_{\text {max-N }}$ is the maximal uptake rate $\left(\mathrm{in} \mathrm{h}^{-1}\right.$ ) and $K_{\mathrm{s}}$ is the half-saturation constant.

(2) If an exponential decrease was noted in the uptake rate of one nutrient (N1) when increasing the concentration of the other (N2), modeled uptake rates and inhibition parameters were determined using the reverse Michaelis-Menten relation (Varela \& Harrison 1999):

$$
V_{\mathrm{N} 1}=V_{\max -\mathrm{N} 1} \times\left\{1-\left(I_{\max } \times[\mathrm{N} 2] /\left(K_{\mathrm{I}}+[\mathrm{N} 2]\right)\right\}\right.
$$

where the $\mathrm{N}$ uptake rate of the nutrient $\mathrm{N} 1, V_{\mathrm{N} 1}$ (in $\mathrm{h}^{-1}$ ), is a function of the maximum uptake rate without inhibition $\left(V_{\text {max-N1}}\right.$, in $\left.\mathrm{h}^{-1}\right)$, the concentration of the inhibitory nutrient ([N2], in $\mu$ gat $\mathrm{N}^{-1}$ ), the maximum inhibition ( $I_{\max }$, values from 0 to 1$)$, and of the inhibition constant $\left(K_{\mathrm{I}}\right.$, concentration of $\mathrm{N} 2$ at which $I=I_{\max } / 2$, in $\mu$ gat $\mathrm{N}^{-1}$ ).

(3) If the variations of total $\mathrm{N}$ uptake rates along a concentration gradient followed saturable kinetics, 'composite' kinetic parameters associated with the total $\mathrm{N}$ flux (from $\mathrm{NH}_{4}{ }^{+}$and urea) were defined using the following equation derived from the MichaelisMenten model:

$$
V_{\mathrm{N} \text {-tot }}=V_{0}+\left(V_{\text {max }- \text { tot }}-V_{0}\right) \times[\mathrm{N}] /\left(K_{\mathrm{s}-\text { tot }}+[\mathrm{N}]\right)
$$

where $V_{\mathrm{N} \text {-tot }}$ is the total $\mathrm{N}$ uptake rate from $\mathrm{NH}_{4}{ }^{+}$and urea (in $\mathrm{h}^{-1}$ ), [N] (in $\mu$ gat $\mathrm{N}^{-1}$ ) is the variable nutrient concentration (the other nutrient concentration being fixed), $V_{0}\left(\mathrm{in}^{-1}\right)$ is the $\mathrm{N}$ uptake rate when $[\mathrm{N}]=0$, and $V_{\text {max-tot }}$ and $K_{\text {s-tot }}$ are the 2 composite parameters equivalent to a maximal total $\mathrm{N}$ uptake rate and a halfsaturation constant for the total $\mathrm{N}$ flux.

Values of kinetic parameters were obtained with Matlab software (The MathWorks), using nonlinear fitting, and minimization of error by least-squares solution).

\section{RESULTS}

\section{Nutrient conditions}

Nutrient concentrations during each experiment (just after resuspension and at the beginning of each experiment part) in terms of $\mathrm{N}$ sources are summarized in Table 1. An $\mathrm{NH}_{4}{ }^{+}$concentration lower than $1.2 \mu_{\text {gatN }}{ }^{-1}$ was ensured at the beginning of each incubation. For $\mathrm{NO}_{3}{ }^{-}$, significant concentrations were measured during experiments and prevented any changes in $\mathrm{N}$ metabolism due to $\mathrm{N}$-deficient condi-

\begin{tabular}{|c|c|c|c|c|c|}
\hline Strain & Origin & Nutrient & $\begin{array}{l}\text { After re- } \\
\text { suspension }\end{array}$ & $\begin{array}{c}\text { Part } \\
1\end{array}$ & $\begin{array}{c}\text { Part } \\
2\end{array}$ \\
\hline VGO565 & $\begin{array}{l}\text { Tarragona } \\
\text { harbor (Spain) }\end{array}$ & $\begin{array}{l}\mathrm{NO}_{3}^{-} \\
\mathrm{NH}_{4}^{+} \\
\text {Urea }\end{array}$ & $\begin{array}{l}4.80 \\
0.41 \\
1.77\end{array}$ & $\begin{array}{l}3.46 \\
0.25 \\
\text { NA }\end{array}$ & $\begin{array}{l}3.19 \\
0.28 \\
1.32\end{array}$ \\
\hline VGO715 & $\begin{array}{l}\text { Barcelona } \\
\text { harbor (Spain) }\end{array}$ & $\begin{array}{l}\mathrm{NO}_{3}^{-} \\
\mathrm{NH}_{4}^{+}\end{array}$ & $\begin{array}{l}5.54 \\
0.36\end{array}$ & $\begin{array}{l}5.65 \\
0.10\end{array}$ & $\begin{array}{l}3.39 \\
1.22\end{array}$ \\
\hline VGO815 & $\begin{array}{l}\text { Thau lagoon } \\
\text { (France) }\end{array}$ & $\begin{array}{l}\mathrm{NO}_{3}^{-} \\
\mathrm{NH}_{4}^{+}\end{array}$ & $\begin{array}{l}4.63 \\
0.32\end{array}$ & $\begin{array}{l}4.20 \\
0.60\end{array}$ & $\begin{array}{l}4.77 \\
0.35\end{array}$ \\
\hline TL01 & $\begin{array}{l}\text { Thau lagoon } \\
\text { (France) }\end{array}$ & $\begin{array}{l}\mathrm{NO}_{3}^{-} \\
\mathrm{NH}_{4}^{+} \\
\text {Urea }\end{array}$ & $\begin{array}{l}2.19 \\
0.40 \\
\text { NA }\end{array}$ & $\begin{array}{l}\text { NA } \\
0.28 \\
0.10\end{array}$ & $\begin{array}{l}\text { NA } \\
0.57 \\
\text { NA }\end{array}$ \\
\hline АСТ03 & $\begin{array}{l}\text { Thau lagoon } \\
\text { (France) }\end{array}$ & $\begin{array}{l}\mathrm{NO}_{3}^{-} \\
\mathrm{NH}_{4}^{+}\end{array}$ & $\begin{array}{l}\text { NA } \\
0.57\end{array}$ & $\begin{array}{l}3.75 \\
0.17\end{array}$ & $\begin{array}{l}\text { NA } \\
0.27\end{array}$ \\
\hline
\end{tabular}

Table 1. Alexandrium catenella. Nutrient concentrations (in $\mu$ gat $\mathrm{N}^{-1}$ ) measured in the culture medium just after the resuspension step and at the beginning of the 2 successive parts of each experiment (Parts 1 and 2). NA: not available 
tions. Such N-free conditions may result in population crashes and/or gametogenesis for this species (Collos et al. 2006).

\section{Influence of urea on $\mathrm{NH}_{4}{ }^{+}$uptake rates}

The influence of urea on the maximal uptake rate of $\mathrm{NH}_{4}{ }^{+}\left(V_{\max }-\mathrm{NH}_{4}{ }^{+}\right)$was analyzed through the variations of ${ }^{15} \mathrm{NH}_{4}{ }^{+}$and ${ }^{15} \mathrm{~N}$-urea uptake data after an addition of 10 ugatN ${ }^{-1}$ of $\mathrm{NH}_{4}{ }^{+}$and along a urea gradient of 0 to

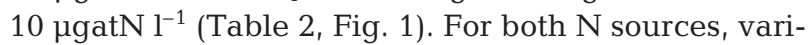
ations of uptake rates along the urea gradient were constrained in similar ranges of values for the 4 strains tested, with high $\mathrm{NH}_{4}{ }^{+}$uptake rates $\left(V_{\mathrm{NH}_{4}+}>0.011 \mathrm{~h}^{-1}\right)$ and very low $\mathrm{N}$-urea uptake rates $\left(V_{\mathrm{N} \text {-urea }}<0.002 \mathrm{~h}^{-1}\right)$ all along the concentration gradient. Uptake data of 2 strains (TL01 and ACT03) are shown in Fig. 1. In this range of nutrient conditions, $V_{\mathrm{NH}_{4}{ }^{+}}$also remained higher than $V_{\mathrm{N} \text {-urea }}$ by a factor of 10 when both nutrients were added at the same concentration.

No trend was observed in variations in $V_{\mathrm{NH}_{4}+}$ along the urea gradient for any strain (Table 2). Thus, the level of urea concentration (between 0 and $10 \mu$ gat $\mathrm{N}^{-1}$ ) has no effect on $\mathrm{NH}_{4}{ }^{+}$uptake by Alexandrium catenella cells when $\mathrm{NH}_{4}{ }^{+}$concentration is high, suggesting no influence of urea concentration on $V_{\text {max }}-\mathrm{NH}_{4}{ }^{+}$.

Regarding $V_{\mathrm{N} \text {-urea }}$ as a function of urea concentration and in the presence of $10 \mu$ gat $\mathrm{I}^{-1}$ of $\mathrm{NH}_{4}{ }^{+}$, particular patterns were displayed for every strain except ACT03 (Fig. 1, dashed lines). These patterns corresponded to Michaelis-Menten kinetics with very low $V_{\max }$ $\left(<0.002 \mathrm{~h}^{-1}\right)$ and $K_{\mathrm{s}}$ values of 0.53 to $3.31 \mu$ gatN ${ }^{-1}$. All parameter values obtained for $V_{\mathrm{N} \text {-urea }}$ versus concentration relationships are summarized in Table 2.

\section{Influence of $\mathrm{NH}_{4}{ }^{+}$on $\mathrm{N}$-urea uptake rates}

The complementary analysis of the $\mathrm{NH}_{4}{ }^{+}$influence on the maximal uptake rate of $\mathrm{N}$-urea ( $V_{\max }$-urea) was based on reverse nutrient conditions: a constant urea concentration of $10 \mu$ gat $\mathrm{N}^{-1}$ and a variable $\mathrm{NH}_{4}{ }^{+}$concentration ( 0 to $10 \mu$ gatN $~^{-1}$ ). Results revealed that $\mathrm{NH}_{4}{ }^{+}$-urea interactions may be an important feature for $\mathrm{N}$ uptake regulation, depending on the strains of Alexandrium catenella.

An $\mathrm{NH}_{4}{ }^{+}$-urea interaction was exclusively observed for the French strains, TL01, ACT03, and VGO815, and was visible through the net decrease of $V_{\mathrm{N} \text {-urea }}$ when $\mathrm{NH}_{4}{ }^{+}$concentration increased. Fig. 2 displays patterns obtained for 2 strains taken as examples (TL01 and ACT03). This interaction corresponded to a strong $\mathrm{NH}_{4}{ }^{+}$inhibition on the $V_{\text {max }}$-urea which could be characterized by fitting the data to reverse MichaelisMenten kinetics. The inhibition parameters obtained (Table 3) corresponded to high maximum inhibition values $\left(I_{\max }>55 \%\right)$ and $K_{\mathrm{I}}$ values of $0.44,1.47$, and

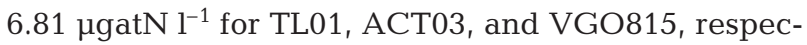
tively. The maximal $\mathrm{N}$-urea uptake rate achieved without $\mathrm{NH}_{4}{ }^{+}$varied from $0.003 \mathrm{~h}^{-1}$ for VGO815 to $0.008 \mathrm{~h}^{-1}$ for ACT03.

For the Spanish strains (VGO715 and VGO565), $V_{\text {N-urea }}$ was more or less constant along the 0 to $10 \mu$ gatN $l^{-1} \mathrm{NH}_{4}{ }^{+}$gradient, with mean uptake values lower than $0.002 \mathrm{~h}^{-1}$ (Table 3). These patterns showed low capacities of these strains to take up $\mathrm{N}$-urea even if urea was the unique $\mathrm{N}$ source and suggested no influence of $\mathrm{NH}_{4}{ }^{+}$concentration on $V_{\text {max }}$-urea for these cells in the range of concentration tested.

Variations of $V_{\mathrm{NH}_{4}+}$ along the $\mathrm{NH}_{4}{ }^{+}$gradient and

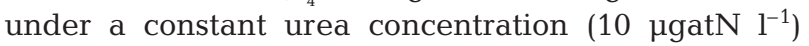
showed similar patterns for the 5 strains tested, corresponding to Michaelis-Menten kinetics. These patterns are presented in Fig. 2 for TL01 and ACT03. Kinetics parameters calculated for all strains are computed in Table 3. Considering $V_{\text {max }}-\mathrm{NH}_{4}{ }^{+}$values in the presence of $10 \mu$ gatN ${ }^{-1}$ of N-urea, ACT03 presented a lower value $\left(0.013 \mathrm{~h}^{-1}\right)$ than other strains of Alexandrium catenella, for which $V_{\text {max }}-\mathrm{NH}_{4}{ }^{+}$ranged from 0.021 to $0.025 \mathrm{~h}^{-1}$. The comparison of $K_{\mathrm{s}}-\mathrm{NH}_{4}{ }^{+}$values separated the strains differently, putting in contrast the

Table 2. Alexandrium catenella. Kinetic parameters $\left(V_{\max }\right.$ in $\mathrm{h}^{-1}$ and $K_{\mathrm{s}}$ in $\left.\mu g a t N l^{-1}\right)$ and mean $( \pm \mathrm{SD})$ uptake rates of $\mathrm{N}$-urea, $\mathrm{NH}_{4}{ }^{+}$, and $V_{\mathrm{N} \text {-tot }}$ obtained along a urea gradient of 0 to $10 \mu$ gatN l ${ }^{-1}$ and after an addition of $10 \mu g a t \mathrm{~N} \mathrm{l}^{-1}$ of $\mathrm{NH}_{4}{ }^{+}$. See 'Materials and methods' for definitions of parameters

\begin{tabular}{|c|c|c|c|c|c|c|}
\hline \multirow[t]{2}{*}{ Strain } & \multirow[t]{2}{*}{ Origin } & \multicolumn{3}{|c|}{$V_{\mathrm{N} \text {-urea }}$ (kinetic parameters) } & \multirow{2}{*}{$V_{\mathrm{NH}_{4}+}$} & \multirow[t]{2}{*}{$V_{\mathrm{N} \text {-tot }}$} \\
\hline & & $V_{\max }$-urea & $K_{\mathrm{s}}$-urea & $\mathrm{r}^{2}$ & & \\
\hline VGO565 & Tarragona (Spain) & 0.0005 & 0.53 & 0.95 & $0.015 \pm 0.001$ & $0.014 \pm 0.001$ \\
\hline VGO715 & Barcelona (Spain) & 0.0012 & 0.86 & 0.89 & $0.021 \pm 0.002$ & $0.022 \pm 0.004$ \\
\hline VGO815 & Thau lagoon (France) & 0.0019 & 0.84 & 0.99 & $0.023 \pm 0.002$ & $0.026 \pm 0.005$ \\
\hline TL01 & Thau lagoon (France) & 0.0020 & 3.31 & 0.93 & $0.019 \pm 0.003$ & $0.019 \pm 0.003$ \\
\hline АCT03 & Thau lagoon (France) & \multicolumn{3}{|c|}{$\begin{array}{c}V_{\mathrm{N} \text {-urea }} \\
0.0006+0.0002\end{array}$} & $0.012 \pm 0.001$ & $0.012 \pm 0.002$ \\
\hline
\end{tabular}




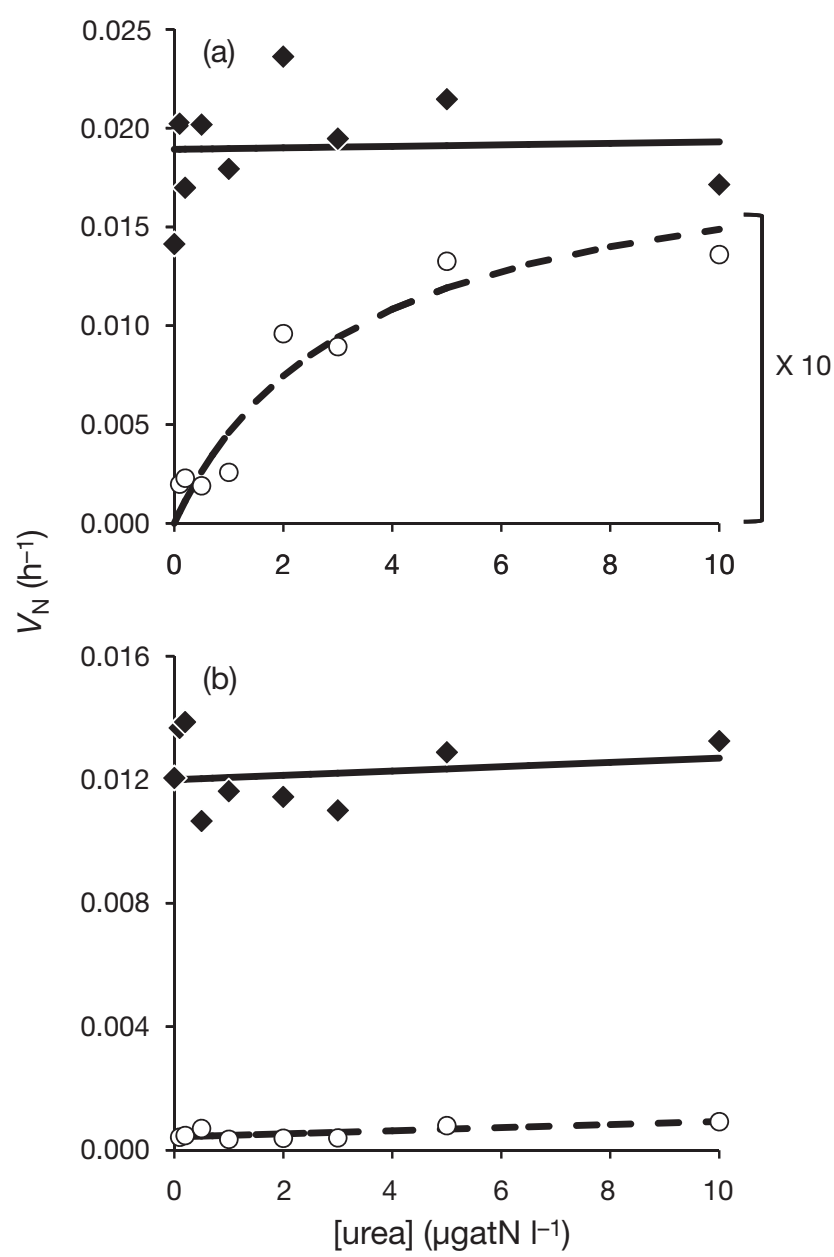

Fig. 1. Alexandrium catenella. Ammonium ( $\bullet$ ) and N-urea uptake rates (O) obtained for the strains (a) TL01 and (b) ACT03 after an addition of $10 \mu$ gatN ${ }^{-1}$ of $\mathrm{NH}_{4}{ }^{+}$and along a graded urea concentration ([urea]) of 0 to $10 \mu$ gatN $~^{-1}$. The modeled curves of $\mathrm{NH}_{4}{ }^{+}$and $\mathrm{N}$-urea uptake data correspond to the solid and dashed lines, respectively. N-urea uptake data for TL01 were multiplied by a factor of 10, as indicated by the bracket

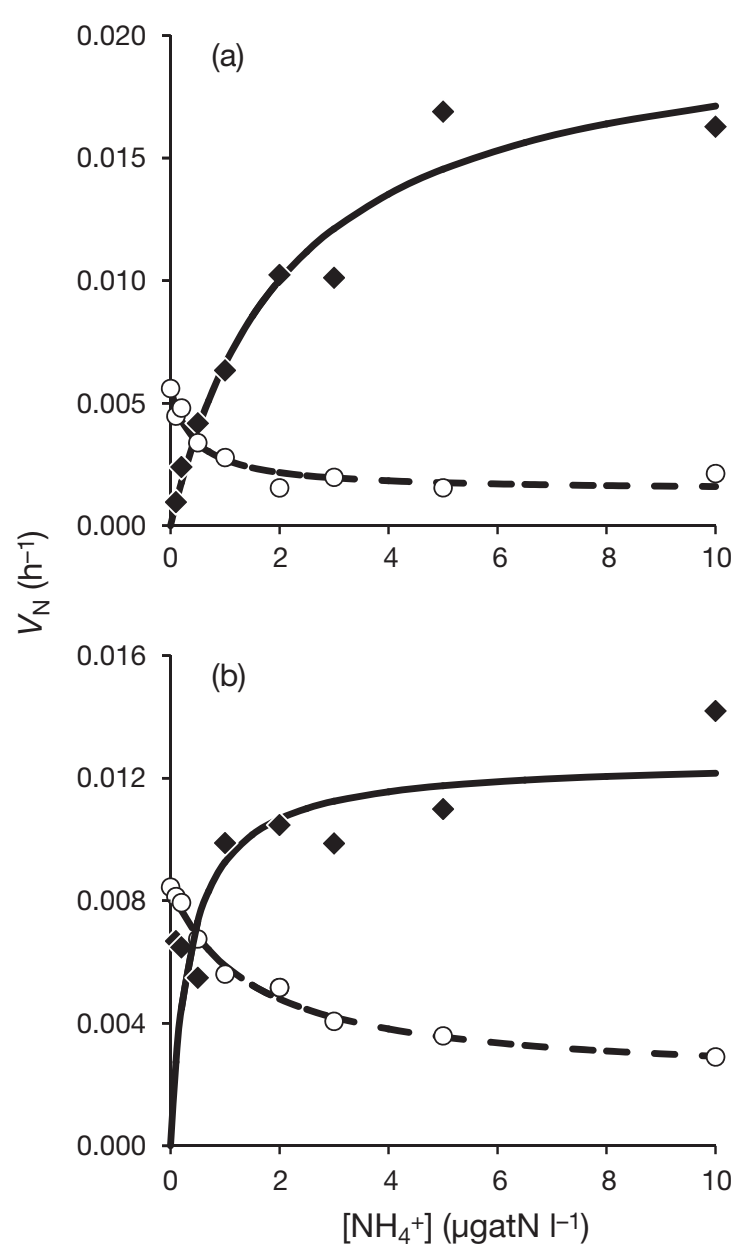

Fig. 2. Alexandrium catenella. Ammonium ( $\bullet$ ) and N-urea uptake rates (O) obtained for the strains (a) TL01 and (b) ACT03 after an addition of $10 \mu$ gatN $~^{-1}$ of urea and along a graded $\mathrm{NH}_{4}{ }^{+}$concentration $\left(\left[\mathrm{NH}_{4}{ }^{+}\right]\right)$of 0 to $10 \mu$ gatN $l^{-1}$. The modeled curves of $\mathrm{NH}_{4}{ }^{+}$and $\mathrm{N}$-urea uptake data correspond to the solid and dashed lines, respectively

Table 3. Alexandrium catenella. Kinetic parameters $\left(V_{\max }\right.$ in $\mathrm{h}^{-1}$ and $K_{\mathrm{s}}$ in $\left.\mu g a t \mathrm{~N} \mathrm{l}^{-1}\right)$, inhibition parameters (N-urea uptake rate without inhibition, $V\left(\left[\mathrm{NH}_{4}^{+}\right]=0\right)$ in $\mathrm{h}^{-1}, I_{\max }$ in $\%$, and $K_{\mathrm{I}}$ in $\mu$ gatN l $\left.{ }^{-1}\right)$ and mean $( \pm \mathrm{SD})$ uptake rates of $\mathrm{N}$-urea, $\mathrm{NH}_{4}{ }^{+}$, and $V_{\mathrm{N} \text {-tot }}$ obtained along an $\mathrm{NH}_{4}^{+}$gradient of 0 to $10 \mu$ gatN l ${ }^{-1}$ and after an addition of $10 \mu$ gat $\mathrm{l}^{-1}$ of urea. See 'Materials and methods' for definitions of parameters

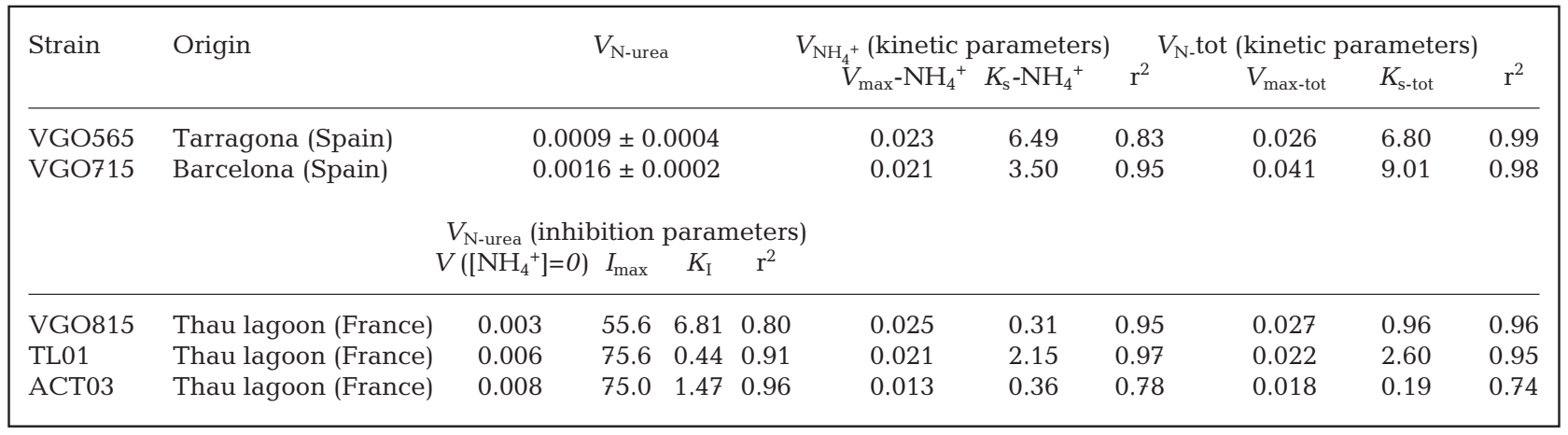



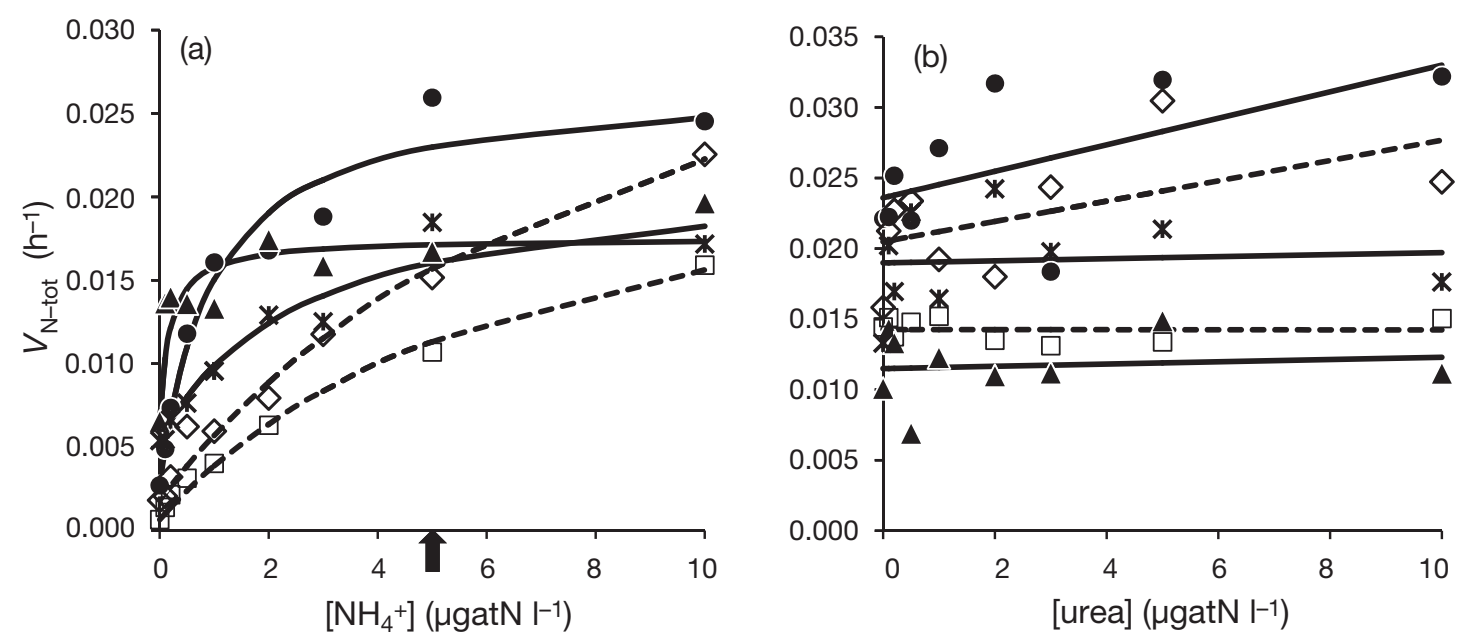

Fig. 3. Alexandrium catenella. Total $\mathrm{N}$ uptake rates (from $\mathrm{NH}_{4}{ }^{+}$and urea) obtained (a) under a constant urea concentration of $10 \mu$ gat $~^{-1}$ coupled with a graded $\mathrm{NH}_{4}{ }^{+}$concentration $\left(\left[\mathrm{NH}_{4}{ }^{+}\right]\right)$of 0 to $10 \mu$ gat $l^{-1}$ and (b) under the reverse nutrients conditions, a constant $\mathrm{NH}_{4}{ }^{+}$concentration of $10 \mu \mathrm{gatN} \mathrm{l^{-1 }}$ coupled with a graded urea concentration ([urea]) of 0 to $10 \mu \mathrm{gatN}{ }^{-1}$. These

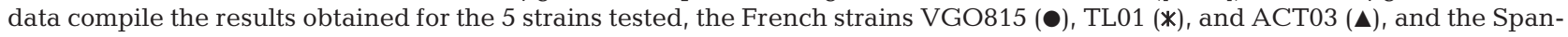
ish strains VGO715 $(\diamond)$ and VGO565 (ㅁ). Modeled curves are represented by solid lines for the French strains and dashed lines for the Spanish strains. The black arrow in (a) points to the threshold concentration of $5 \mu \mathrm{gatN}^{-1}$

French strains $\left(K_{\mathrm{s}}-\mathrm{NH}_{4}{ }^{+}<2.2 \mu \mathrm{gatN}^{-1}\right)$ to the Spanish strains $\left(K_{\mathrm{s}}-\mathrm{NH}_{4}{ }^{+}>3.5 \mu \mathrm{gatN}{ }^{-1}\right)$ when a high urea concentration was added.

\section{Total $\mathbf{N}$ fluxes}

Data of the summed uptake rates of $\mathrm{NH}_{4}{ }^{+}$and Nurea (total $\mathrm{N}$ uptake rates, $V_{\mathrm{N} \text {-tot }}$ ) represent $\mathrm{N}$ uptake capacities when both nutrients are present in the medium and reflect the competitiveness of each strain in these multi-nutrient conditions. Results obtained along the urea gradient and the $\mathrm{NH}_{4}{ }^{+}$gradient are presented in Fig. 3a and b, respectively. Similar patterns were observed for the 5 strains along the varying nutrients conditions, with 2 different kinds of variations depending on the nutrient gradient tested.

When urea concentration was high $\left(10 \mu\right.$ gat $\left.\mathrm{l}^{-1}\right)$, $V_{\mathrm{N} \text {-tot }}$ increased with increasing $\mathrm{NH}_{4}{ }^{+}$concentration according to Michaelis-Menten kinetics for the 5 strains (Fig. 3a). The composite kinetic parameter values for the total $\mathrm{N}$ fluxes are summarized in Table 3. Contrary to $V_{\text {max-tot }}$ values, the comparison of $K_{\text {s-tot }}$ values between strains highlights 2 contrasting groups: the French strains $\left(K_{\text {s-tot }} \leq 2.6 \mu \mathrm{gatN}^{-1}\right)$ and the Spanish strains $\left(K_{\text {s-tot }} \geq 6.8 \mu\right.$ gatN l $\left.{ }^{-1}\right)$. This difference in $K_{\text {s-tot }}$ suggests higher $\mathrm{N}$ uptake capacities for the French strains at low $\mathrm{NH}_{4}{ }^{+}$concentration when the urea concentration is high $\left(10 \mu \mathrm{gatN}^{-1}\right)$. This was confirmed by the fact that $V_{\mathrm{N} \text {-tot }}$ mean values of the French strains were significantly different (2-tailed paired t-test using GraphPad Prism version 4.00 for OSX, GraphPad Software) from those of the Spanish strains below $5 \mu \mathrm{M} \mathrm{NH}_{4}{ }^{+}$(arrow in Fig. 3a), while they were not for the other concentration values.

No clear trend in $V_{\mathrm{N} \text {-tot }}$ could be defined along the urea gradient ( 0 to $10 \mu \mathrm{gatN}^{-1}$ ) with an addition of 10 ugatN l-1 of $\mathrm{NH}_{4}{ }^{+}$(Fig. 3b). Estimation of $V_{\mathrm{N} \text {-tot }}$ mean values through the urea gradient (Table 2) allows for the assessment of the N-uptake capacities of each strain under a high $\mathrm{NH}_{4}{ }^{+}$concentration, whatever the urea concentration. The range of mean values obtained is bracketed by 2 French strains, VGO815 and ACT03. With a $V_{\mathrm{N} \text {-tot }}$ mean value of $0.026 \pm$ $0.005 \mathrm{~h}^{-1}$, VGO815 appeared to be the most competitive strain when the $\mathrm{NH}_{4}{ }^{+}$concentration was high. Conversely, ACT03 showed poor competitive abilities $\left(V_{\mathrm{N} \text {-tot }}\right.$ mean value of $\left.0.012 \pm 0.002 \mathrm{~h}^{-1}\right)$ under the same nutrient conditions.

\section{DISCUSSION}

Even if $\mathrm{NO}_{3}{ }^{-}$may be considered as a potential interfering factor for $\mathrm{NH}_{4}{ }^{+}$and $\mathrm{N}$-urea uptake estimations in the present results, its influence is probably negligible. Stock cultures grown on an $\mathrm{NO}_{3}{ }^{-}$based medium could lead to underestimations of $\mathrm{NH}_{4}{ }^{+}$and $\mathrm{N}$-urea uptake rates due to pre-conditioning effects. However, from short time-series experiments using French and Spanish strains of Alexandrium catenella, Jauzein et al. (2008) obtained linear trends in uptake rates of 
$\mathrm{NH}_{4}{ }^{+}$and $\mathrm{N}$-urea with time over $1 \mathrm{~h}$, following the same protocol. Such trends allowed us to reject any potential interference associated with pre-conditioning effects as well as with surge uptake processes due to maintenance under low $\mathrm{N}$ conditions before starting incubations. Furthermore, significant $\mathrm{NO}_{3}{ }^{-}$concentrations measured during experiments require the potential effect of $\mathrm{NO}_{3}{ }^{-}$on $\mathrm{NH}_{4}{ }^{+}$and $\mathrm{N}$-urea uptake to be assessed. Concerning $\mathrm{NH}_{4}{ }^{+}$uptake, $\mathrm{NO}_{3}{ }^{-}$has sometimes been reported to reduce its uptake, but the effect was only slight (2 to $15 \%$ ) in Monochrysis lutheri (Caperon \& Ziemann 1976) and Skeletonema costatum (Dortch \& Conway 1984). Larger effects were only observed either in N-deficient cells (Dortch \& Conway 1984) or at values above $8 \mu \mathrm{M} \mathrm{NO}_{3}{ }^{-}$(Cochlan \& Harrison 1991). No effect was reported by Terry (1982) on Thalassiosira weissflogii, Nakamura (1985) on Chatonella, and Lund (1987) on S. costatum, even at $10 \mu \mathrm{M}$ $\mathrm{NO}_{3}{ }^{-}$. Similar characteristics have been reported for the potential interaction between $\mathrm{NO}_{3}{ }^{-}$and $\mathrm{N}$-urea. The influence of $\mathrm{NO}_{3}{ }^{-}$on $\mathrm{N}$-urea uptake has only been reported by Lund (1987) for S. costatum and by Molloy \& Syrett (1988) for Chlorella emersonii and Phaeodactylum tricornutum. In these studies, N-urea uptake was reduced by only 10 to $24 \%$ at respective levels of 10 and $10000 \mu \mathrm{M} \mathrm{NO}_{3}{ }^{-}$. No effect of $\mathrm{NO}_{3}{ }^{-}(40$ to $50 \mu \mathrm{M})$ was evident from data of Grant et al. (1967) and Waser et al. (1998) on 4 species of marine phytoplankton. Given that $\mathrm{NO}_{3}{ }^{-}$concentrations were always under $5.7 \mu \mathrm{M}$ during our experiments (Table 1) and cells were $\mathrm{N}$-sufficient, we assumed that interaction with $\mathrm{NO}_{3}{ }^{-}$may be considered as not interfering in the trends observed for $\mathrm{NH}_{4}{ }^{+}$and $\mathrm{N}$-urea uptake.

For all strains, a difference by a factor of 10 was observed between $V_{\mathrm{NH}_{4}+}$ and $V_{\mathrm{N} \text {-urea }}$ values after an addition of 10 ugatN $l^{-1}$ of $\mathrm{NH}_{4}^{+}$. This discrepancy implies low capacities of Alexandrium catenella cells to take up $\mathrm{N}$-urea when $\mathrm{NH}_{4}{ }^{+}$concentration in the medium is high. Depending on the strains, this $\mathrm{N}$ uptake characteristic may be explained by low intrinsic $\mathrm{N}$-urea uptake capacities or by an $\mathrm{NH}_{4}{ }^{+}$-urea interaction.

\section{Characteristics of the $\mathrm{NH}_{4}{ }^{+}$inhibition of urea uptake}

Among all potential interactions between $\mathrm{N}$ sources available for phytoplankton growth, most ecological studies have focused on the $\mathrm{NH}_{4}{ }^{+}$effect on $\mathrm{NO}_{3}{ }^{-}$ uptake (Dortch 1990 and references therein). The results of the present study point out the importance of another potential nutrient interaction with the strong inhibition of $\mathrm{NH}_{4}^{+}$on urea uptake noted for Thau lagoon strains of Alexandrium catenella. Even if only a few studies have been conducted on this interaction, such an $\mathrm{NH}_{4}{ }^{+}$inhibition of urea uptake has been previously observed for other phytoplankton taxa, such as diatoms (Horrigan \& McCarthy 1982, Lund 1987) or freshwater cyanobacteria and chlorophytes (Healey 1977), and for field plankton communities (McCarthy \& Eppley 1972, Irmisch 1991, Tamminen \& Irmisch 1996). The inhibition characteristics reported in these previous studies show a high variability, both for the level of inhibition observed (from 15\% to $90 \%$ ) and for the threshold of $\mathrm{NH}_{4}{ }^{+}$concentration needed to depress urea uptake. The only 2 studies that present inhibition data along an $\mathrm{NH}_{4}{ }^{+}$gradient reported 2 distant threshold values, $2 \mu$ gatN $~^{-1}$ in the study of Healey (1977) and $50 \mu$ gatN $~^{-1}$ in the work of Tamminen \& Irmisch (1996). Another difference in the inhibition characteristics may also be noted in the time scale over which the inhibition process is implemented. The $\mathrm{NH}_{4}{ }^{+}$addition may induce an instantaneous decrease in urea uptake (Lund 1987) or after a time lag as observed in cases reported by Horrigan \& McCarthy (1982) and Tamminen \& Irmisch (1996). Such differences in the reactivity time may suggest differences in the control of the inhibition process. An immediate inhibition effect may indicate a direct repression of the urea transport activity, while a time lag may reflect a more complex regulation system such as a disruption of the synthesis/degradation cycle in transport proteins or a control system by an internal pool.

The $\mathrm{NH}_{4}{ }^{+}$-urea interaction observed in the present study was strictly an $\mathrm{NH}_{4}{ }^{+}$inhibition of urea uptake, and more precisely on the $V_{\max }$-urea according to the protocol employed. This 'one way' interaction contrasts with the results of the 2 previous studies where mutual interaction experiments were conducted (Healey 1977, Lund 1987), and for which the $\mathrm{NH}_{4}{ }^{+}$inhibition of urea uptake was coupled with a parallel inhibition of urea on $\mathrm{NH}_{4}{ }^{+}$uptake. The use of an inhibitor concentration gradient ranging from 0.1 to $10 \mu$ gat $\mathrm{N}^{-1}$ has led to a visualization of a regular hyperbolic decrease of urea uptake with increasing $\mathrm{NH}_{4}^{+}$concentration. This detailed pattern of the $\mathrm{NH}_{4}{ }^{+}$inhibition of urea uptake is the first reported for phytoplankton species and allows characterization of the $\mathrm{NH}_{4}{ }^{+}$-urea interaction using an adequate modeling approach.

To date, studies on $\mathrm{NH}_{4}{ }^{+}-\mathrm{NO}_{3}{ }^{-}$interactions have led to the most abundant available data on nutrient interactions, resulting from 4 decades of experiments (Dortch 1990 and references therein). This well documented $\mathrm{NH}_{4}{ }^{+}-\mathrm{NO}_{3}{ }^{-}$interaction has allowed a strong modeling effort, from laboratory experiments to marine ecosystem models (e.g. Sarmiento et al. 1993, Chapelle et al. 2000). Numerous mathematical formulations have been proposed to simulate the co-limitation between these nutrients, making the interaction modeling somehow confusing (Tian 2006) when the 
choice among them may be critical in the case of ecosystem simulation (Andersen \& Heibig 1998, Sharada et al. 2005). The lack of knowledge on the processes involved in the $\mathrm{NH}_{4}{ }^{+}$-urea interaction makes the mechanistic models, relying on uptake regulation by feedback mechanisms and internal biochemical pools (e.g. Flynn 2001), too complex to simulate this inhibition. A modeling approach referring only to external nutrient concentrations appears to be adequate in the present case. When modeling the $\mathrm{NH}_{4}{ }^{+}-\mathrm{NO}_{3}{ }^{-}$interaction, modelers usually set as a postulate that $V_{\max }-\mathrm{N} 1 / V_{\max }-\mathrm{N} 2=1$, where $V_{\max }-\mathrm{N} 1$ and $V_{\text {max }}-\mathrm{N} 2$ are the maximal uptake rates of both nutrients without interaction processes. However, this relation may not be verified in the case of the $\mathrm{NH}_{4}{ }^{+}$-urea interaction. Even if the results of Collos et al. (2004) on the nitrogenous nutrition of Alexandrium catenella cells presented similar values for $V_{\max }-\mathrm{NH}_{4}{ }^{+}$and $V_{\max }$-urea, the present investigation demonstrates that it was not the case for all strains of $A$. catenella.

Following the recommendations of Sharada et al. (2005) and Tian (2006), 2 formulations (Parker 1993, Varela \& Harrison 1999) were tested with our data. The equation proposed by Varela \& Harrison (1999) appeared to generate the most efficient simulation of the inhibition process observed for Thau lagoon strains. The accuracy of this formulation is strengthened by the fact that it gathers the 3 essential properties defined by Sharada et al. (2005), i.e. similarity, hyperbolicity, and incomplete inhibition.

From the model fitting, the inhibition parameters $I_{\max }$ (maximum inhibition) and $K_{\mathrm{I}}$ (inhibition constant) were generated and allow characterization of the urea uptake inhibition observed for the Thau lagoon strains of Alexandrium catenella. The TL01 and ACT03 strains showed an inhibition of urea uptake that was particularly strong $\left(I_{\max } \geq 75 \%\right)$ and sensitive to $\mathrm{NH}_{4}{ }^{+}$ concentration $\left(K_{\mathrm{I}} \leq 1.47 \mu \mathrm{gatN}^{-1}\right)$. The range of values obtained for $I_{\max }$ and $K_{\mathrm{I}}$ appears to be similar to that reported for the $\mathrm{NH}_{4}{ }^{+}$inhibition on $\mathrm{NO}_{3}{ }^{-}$uptake of the dinoflagellates A. minutum (Maguer et al. 2007), Prorocentrum minimum, and Gyrodinium uncatenum (Lomas \& Glibert 1999). However, this similarity is not sufficient to assume identical mechanisms of regulation between these distinct interactions.

The influence of $\mathrm{NH}_{4}{ }^{+}$concentration on N-urea assimilation by Alexandrium catenella cells may not be restricted to the uptake process. For A. catenella, the assimilation of $\mathrm{N}$-urea involves the enzyme urease (Dyhrman \& Anderson 2003). An inhibition of the activity of this enzyme by $\mathrm{NH}_{4}{ }^{+}$concentration has been previously reported for diatoms (Lomas 2004) and freshwater cyanobacteria (Singh 1992), pointing out the interest of studying such a potential influence for A. catenella.

\section{Variability between strains and ecological considerations}

From the estimation of total $\mathrm{N}$ uptake rates (from $\mathrm{NH}_{4}{ }^{+}$and $\mathrm{N}$-urea, $V_{\mathrm{N} \text {-tot }}$ ), it is possible to describe further aspects of the control of $\mathrm{N}$ uptake by Alexandrium catenella cells and to compare $\mathrm{N}$ uptake capacities of the different strains in a range of nutrient conditions. For all strains, $V_{\mathrm{N} \text {-tot }}$ was mostly constant along the urea gradient, whereas an increase was observed along the $\mathrm{NH}_{4}{ }^{+}$gradient. This suggests that the total $\mathrm{N}$ uptake by $A$. catenella cells may be mainly governed by the $\mathrm{NH}_{4}{ }^{+}$concentration when both nutrients are present. In addition, the strong inhibition of $\mathrm{NH}_{4}{ }^{+}$on $\mathrm{N}$-urea uptake noted for the French strains enhances the importance of this $\mathrm{NH}_{4}^{+}$ control of total $\mathrm{N}$ flux for these strains. In this particular case, the increase in $V_{\mathrm{N} \text {-tot }}$ along the $\mathrm{NH}_{4}{ }^{+}$gradient arises from the compilation of 2 inverse trends: a decrease in $V_{\mathrm{N} \text {-urea }}$ together with an increase in $V_{\mathrm{NH}_{4}{ }^{+}}$. This suggests that $\mathrm{N}$-urea uptake losses induced by $\mathrm{NH}_{4}{ }^{+}$inhibition were more than compensated for by the $\mathrm{NH}_{4}{ }^{+}$uptake. Such a compensatory effect may also be noted in the results of Healey (1977) and Lund (1987) on other phytoplankton species and points out that the $\mathrm{NH}_{4}{ }^{+}$inhibition of $\mathrm{N}$-urea uptake is not a competitive disadvantage for these cells. Moreover, this compensation of the $\mathrm{NH}_{4}{ }^{+}$inhibition allows an increase in $V_{\mathrm{N} \text {-tot }}$ with the diversification of the potential $\mathrm{N}$ sources. A similar consideration may be made for the Spanish strains but from the lack of $\mathrm{NH}_{4}{ }^{+}$-urea interaction.

Considering the $V_{\mathrm{N} \text {-tot }}$ values obtained along the $\mathrm{NH}_{4}{ }^{+}$gradient, French strains appeared to be more competitive than the Spanish ones in an environment characterized by $\mathrm{NH}_{4}{ }^{+}$concentration below 5 ugatN $\mathrm{l}^{-1}$ (see Fig. 3) and high urea (as $10 \mu$ gatN $\mathrm{l}^{-1}$ ) concentrations. This competitive ability may be explained by better capacities of the French strains to take up $\mathrm{NH}_{4}{ }^{+}$at low concentrations (lower $K_{\mathrm{s}}-\mathrm{NH}_{4}{ }^{+}$ than the Spanish strains) but also by higher capacities to take up $\mathrm{N}$-urea when the $\mathrm{NH}_{4}{ }^{+}$concentration is low, in particular for the ACT03 strain. These uptake capacities may be examined relative to the nutrient conditions reported for each originating area of the strains. Ranges of dissolved inorganic nitrogen concentrations during Alexandrium catenella blooms are usually higher in Barcelona and Tarragona harbors in Spain (0.4 to $36 \mu$ gatN l${ }^{-1}$ of $\mathrm{NO}_{3}{ }^{-}$; 0.1 to $17.9 \mu$ gatN $\mathrm{l}^{-1}$ of $\mathrm{NH}_{4}^{+}$) than in Thau lagoon in France (0.1 to 4.4 ugatN ${ }^{-1}$ of $\mathrm{NO}_{3}^{-}$; 0.2 to $9.6 \mu$ gatN ${ }^{-1}$ of $\mathrm{NH}_{4}^{+}$; Ifremer and Institut de Ciències del Mar unpubl. data collected in 2000 to 2003 from 2 and 4 blooms, respectively, for French and Spanish sites). Furthermore, high dissolved organic nitrogen concentrations 
(up to 26 ugatN $\mathrm{l}^{-1}$ ) have been measured during these blooms in Thau lagoon. Thus, the differences noted in $K_{S}$ tot values between Spanish and French strains may reflect particular metabolic adaptations of the strains to their respective environment.

Although French strains appear well adapted to an environment with low $\mathrm{NH}_{4}{ }^{+}$concentration, they present different ranges of optimal nutrient conditions. For example, with a high $V_{\max }-\mathrm{NH}_{4}{ }^{+}$coupled with a low $K_{\mathrm{s}}-\mathrm{NH}_{4}{ }^{+}, \mathrm{VGO} 815$ showed competitive abilities to take up $\mathrm{NH}_{4}{ }^{+}$under a large range of $\mathrm{NH}_{4}{ }^{+}$concentrations, whatever the urea concentration. With the lowest $V_{\text {max }}-\mathrm{NH}_{4}{ }^{+}$, ACT03 did not show efficient $\mathrm{N}$-uptake capacities when the $\mathrm{NH}_{4}{ }^{+}$concentration was high but presented the highest ability to use urea as a major $\mathrm{N}$ source when $\mathrm{NH}_{4}{ }^{+}$concentration was low. Such diversity between strains of the same originating area allows us to consider 2 potential ecological strategies for Alexandrium catenella, which can be called adaptability or efficiency. If the strategy points to adaptability, no selection of N-uptake characteristics occurs from nutrient conditions during the bloom development, keeping the diversity in $\mathrm{N}$-uptake capacities at the population level. In this case, the global N-uptake rate of the population may be maintained even if the environmental conditions vary but an optimal uptake and competitiveness are prevented. The efficiency strategy requires a selection phase of the cells. It leads to a population well adapted to the instantaneous environmental conditions with an optimal $\mathrm{N}$ uptake but very sensitive to changes in nutrient conditions. Only a biomolecular approach of the genetic variability of blooming A. catenella cells may give broad insight on the ecological strategies encountered in the field and on the potential selection of genotypic and phenotypic characteristics.

\section{CONCLUSION}

Ammonium concentration appeared to be the main factor controlling $\mathrm{N}$ uptake by Alexandrium catenella cells when $\mathrm{NH}_{4}{ }^{+}$and urea are simultaneously present in the medium. For the French strains tested, this control is reinforced by a strong inhibition of $\mathrm{NH}_{4}^{+}$on $\mathrm{N}$ urea uptake. The potential influence of $\mathrm{NH}_{4}{ }^{+}$on the urease activity of these cells must be analyzed to achieve a complete understanding of the control of $\mathrm{N}$ urea assimilation. This understanding is complicated by a high variability noted between strains of $A$. catenella. If part of this variability may be associated with environmental adaptations, this diversity allows a potential selection of the cells during bloom developments with regard to their $\mathrm{NH}_{4}^{+}$and $\mathrm{N}$-urea uptake characteristics.
Acknowledgements. We thank R. Ventosa for the nutrient analyses. This study was financed by the Centre National de la Recherche Scientifique (CNRS) and Institut Français pour l'Exploitation de la Mer (Ifremer) ALTOX program, as well as the EU-funded Research Project SEED (Life cycle transformations among HAB species, and the environmental and physiological factors that regulate them, GOCE-CT-2005-003875). S.L. was supported by a Fundação para a Ciência e para a Tecnologia, Portugal (FCT) grant within the III Quadro Comunitário de Apoio by the Fundo Social Europeu. E.G. was supported by the Ramon y Cajal contract of the Spanish Ministry of Education and Science. C.J. was supported by a scholarship from the Région Languedoc-Roussillon and Ifremer.

\section{LITERATURE CITED}

Andersen V, Heibig A (1998) Modelling nitrate and ammonium uptake by phytoplankton. Influence of the formulation in an ecosystem model. Bull Soc R Sci Liège 67:3-21

Andersen RA, Berges JA, Harrison PJ, Watanabe MM (2005) Recipes for freshwater and seawater media. In: Andersen RA (ed) Algal culturing techniques. Elsevier, Amsterdam, p 429-538

> Bec B, Husseini-Ratrema J, Collos Y, Souchu P, Vaquer A (2005) Phytoplankton seasonal dynamics in a Mediterranean coastal lagoon: emphasis on the picoeukaryote community. J Plankton Res 27:881-894

Caperon J, Ziemann DA (1976) Synergistic effects of nitrate and ammonium on growth and uptake kinetics of Monochrysis lutheri in continuous culture. Mar Biol 36:73-84

$>$ Chapelle A, Menesguen A, Deslous-Paoli JM, Souchu P, Mazouni N, Vaquer A, Millet B (2000) Modelling nitrogen, primary production and oxygen in a Mediterranean lagoon. Impact of oysters farming and inputs from the watershed. Ecol Model 127:161-181

Cochlan WP, Harrison PJ (1991) Inhibition of nitrate uptake by ammonium and urea in the eucaryotic picoflagellate Micromonas pusilla (Butcher) Manton et Parke. J Exp Mar Biol Ecol 153:143-152

Collos Y (1987) Calculations of N-15 uptake rates by phytoplankton assimilating one or several nitrogen sources. Appl Radiat Isot 38:275-282

Collos Y, Mornet F, Sciandra A, Waser N, Larson A, Harrison PJ (1999) An optical method for the rapid measurement of micromolar concentrations of nitrate in marine phytoplankton cultures. J Appl Phycol 11:179-184

Collos Y, Gagne C, Laabir M, Vaquer A, Cecchi P, Souchu P (2004) Nitrogenous nutrition of Alexandrium catenella (Dinophyceae) in cultures and in Thau lagoon, southern France. J Phycol 40:96-103

Collos Y, Lespilette M, Vaquer A, Laabir M, Pastoureaud A (2006) Uptake and accumulation of ammonium by Alexandrium catenella during nutrient pulses. Afr J Mar Sci 28:313-318

Collos Y, Vaquer A, Laabir M, Abadie E, Laugier T, Pastoureaud A, Souch P (2007) Contribution of several nitrogen sources to growth of Alexandrium catenella during blooms in Thau lagoon, southern France. Harmful Algae 6:781-789

> Dortch Q (1990) The interaction between ammonium and nitrate uptake in phytoplankton. Mar Ecol Prog Ser 61: 183-201

> Dortch Q, Conway HL (1984) Interactions between nitrate and ammonium uptake-variation with growth rate, nitrogen source and species. Mar Biol 79:151-164

Dyhrman ST, Anderson DM (2003) Urease activity in cultures 
and field populations of the toxic dinoflagellate Alexandrium. Limnol Oceanogr 48:647-655

Eppley RW, Sharp JH, Renger EH, Perry MJ, Harrison WG (1977) Nitrogen assimilation by phytoplankton and other microorganisms in the surface waters of the central North Pacific Ocean. Mar Biol 39:111-120

> Flynn KJ (2001) A mechanistic model for describing dynamic multi-nutrient, light, temperature interactions in phytoplankton. J Plankton Res 23:977-997

Garcés E, Vila M, Masó M, Sampedro N, Giacobbe MG, Penna A (2005) Taxon-specific analysis of growth and mortality rates of harmful dinoflagellates during bloom conditions. Mar Ecol Prog Ser 301:67-79

> Glibert PM, Harrison J, Heil C, Seitzinger S (2006) Escalating worldwide use of urea - a global change contributing to coastal eutrophication. Biogeochemistry 77:441-463

Goeyens L, Kindermans N, Abu Yusuf M, Elskens M (1998) A room temperature procedure for the manual determination of urea in seawater. Estuar Coast Shelf Sci 47: $415-418$

> Grant BR, Madgwick J, DalPont G (1967) Growth of Cylindrotheca closterium var. californica (Mereschk) Rieman \& Lewin on nitrate, ammonia, and urea. Aust J Mar Freshw Res 18:129-135

Grasshoff K, Ehrardt M, Kremling K (1983) Methods of sea water analysis. Verlag Chemie, Weinheim

Guillard RRL, Ryther JH (1962) Studies of marine planktonic diatoms. I. Cyclotella nana Hustedt and Detonula confervacea (Cleve) Gran. Can J Microbiol 8:229-239

Healey FP (1977) Ammonium and urea uptake by some freshwater algae. Can J Bot 55:61-69

> Horrigan SG, McCarthy JJ (1982) Phytoplankton uptake of ammonium and urea during growth on oxidized forms of nitrogen. J Plankton Res 4:379-389

Irmisch A (1991) Investigations on the urea uptake by phytoplankton in the Baltic Sea. Acta Hydrochim Hydrobiol 19: 39-44

Jauzein C, Collos Y, Garcès E, Vila M, Maso M (2008) Shortterm temporal variability of ammonium and urea uptake by Alexandrium catenella (Dynophyta) in cultures. J Phycol 44:1136-1145

Koroleff F (1976) Determination of nutrients. In: Grasshoff K (ed) Methods of seawater analysis. Verlag Chemie, Weinheim, p 117-182

Kristiansen S, Lund BA (1989) Nitrogen cycling in the Barents Sea-I. Uptake of nitrogen in the water column. Deep-Sea Res 36:255-268

Lilly EL, Kulis DM, Gentien P, Anderson DM (2002) Paralytic shellfish poisoning toxins in France linked to a humanintroduced strain of Alexandrium catenella from the western Pacific: evidence from DNA and toxin analysis. J Plankton Res 24:443-452

> Lomas MW (2004) Nitrate reductase and urease enzyme activity in the marine diatom Thalossiosira weissflogii (Bacillariophyceae): interactions among nitrogen substrates. Mar Biol 144:37-44

> Lomas MW, Glibert PM (1999) Interactions between $\mathrm{NH}_{4}{ }^{+}$ and $\mathrm{NO}_{3}{ }^{-}$uptake and assimilation: comparison of diatoms and dinoflagellates at several growth temperatures. Mar Biol 133:541-551

Lund BA (1987) Mutual interference of ammonium, nitrate, and urea on uptake of $\mathrm{N}-15$ sources by the marine diatom Skeletonema costatum (Grev) Cleve. J Exp Mar Biol Ecol 113:167-180

Editorial responsibility: Hugh MacIntyre,

Dauphin Island, Alabama, USA
Maguer JF, L'Helguen S, Madec C, Labry C, Le Corre P (2007) Nitrogen uptake and assimilation kinetics in Alexandrium minutum (Dynophyceae): effect of N-limited growth rate on nitrate and ammonium interactions. J Phycol 43:295-303

McCarthy JJ, Eppley RW (1972) A comparison of chemical, isotopic, and enzymatic methods for measuring nitrogen assimilation of marine phytoplankton. Limnol Oceanogr 17:371-382

Molloy CJ, Syrett PJ (1988) Effect of light and N deprivation on inhibition of nitrate uptake by urea in microalgae. J Exp Mar Biol Ecol 118:97-101

> Nakamura Y (1985) Ammonium uptake kinetics and interactions between nitrate and ammonium uptake in Chattonella antiqua. J Oceanogr Soc Jpn 41:33-38

> Parker RA (1993) Dynamic models for ammonium inhibition of nitrate uptake by phytoplankton. Ecol Model 66: $113-120$

Price NM, Harrison PJ (1988) Uptake of urea C and urea N by the costal marine diatom Thalassiosira pseudonana. Limnol Oceanogr 33:528-537

Rausch de Traubenberg C, Soyer-Gobillard MO (1990) Bacteria associated with a photosynthetic dinoflagellate in culture. Symbiosis 8:117-133

Rees TAV, Bekheet IA (1982) The role of nickel in urea assimilation by algae. Planta 156:385-387

Sahlsten E (1987) Nitrogenous nutrition in the euphotic zone of the Central North Pacific Gyre. Mar Biol 96:433-439

> Sarmiento JL, Slater RD, Fasham MJR, Ducklow HW, Toggweiler JR, Evans GT (1993) A seasonal 3-dimensional ecosystem model of nitrogen cycling in the North-Atlantic euphotic zone. Global Biogeochem Cycles 7:417-450

Sharada MK, Yajnik KS, Swathi PS (2005) Evaluation of six relations of the kinetics of uptake by phytoplankton in multi-nutrient environment using JGOFS experimental results. Deep-Sea Res II 52:1892-1909

Singh S (1992) Regulation of urease cellular levels in the cyanobacteria Anacystis nidulans and Nostoc muscorum. Biochem Physiol Pflanz 188:33-38

Tamminen T, Irmisch A (1996) Urea uptake kinetics of a midsummer planktonic community on the SW coast of Finland. Mar Ecol Prog Ser 130:201-211

Terry KL (1982) Nitrate uptake and assimilation in Thalassiosira weissflogii and Phaeodactylum tricornutum: interactions with photosynthesis and with uptake of other ions. Mar Biol 69:21-30

- Tian RCC (2006) Toward standard parameterizations in marine biological modeling. Ecol Model 193:363-386

Uchida T (1976) Excretion of ammonia by Prorocentrum micans Ehrenberg in urea-grown culture. Jpn J Ecol 26: 43-44

> Varela DE, Harrison PJ (1999) Effect of ammonium on nitrate utilization by Emiliania huxleyi, a coccolithophore from the oceanic northeastern Pacific. Mar Ecol Prog Ser 186: $67-74$

- Vila M, Garcés E, Masó M, Camp J (2001) Is the distribution of the toxic dinoflagellate Alexandrium catenella expanding along the NW Mediterranean coast? Mar Ecol Prog Ser 222:73-83

Waser NA, Yin K, Yu Z, Ada K, Harrison AJ, Turpin DH, Calvert SE (1998) Nitrogen isotope fractionation during nitrate, ammonium and urea uptake by marine diatoms and coccolithophores under various conditions of $\mathrm{N}$ availability. Mar Ecol Prog Ser 169:29-41

Submitted: April 10, 2008; Accepted: September 15, 2008

Proofs received from author(s): November 28, 2008 